\title{
In vitro Study on the Efficacy of Silver Nanoparticles against Metallo-Beta- Lactamase and Biofilm Producing Pseudomonas aeruginosa Isolates
}

\author{
Marwa Gamal Bahey ${ }^{1 *}$, Abou El Fetouh Eid El Enany ${ }^{1}$, Mohamed Ismaeil Abd El \\ Hamid $^{1}$, Aziza Mahmoud Hassan ${ }^{1}$ and Lobna Mohamed Abo Elnasr ${ }^{2}$ \\ ${ }^{1}$ Medical Microbiology \& Immunology Department, Faculty of Medicine, \\ Tanta University, Egypt \\ ${ }^{2}$ Anesthesia and Surgical ICU Department, Faculty of Medicine, \\ Tanta University, Egypt \\ *Corresponding author
}

A B S T R A C T

\section{Keywords \\ Silver \\ nanoparticles, \\ Pseudomonas \\ aeruginosa, Metallo \\ Beta Lactamase, \\ Biofilm, \\ Transmission \\ Electron \\ Microscope, \\ Confocal Laser \\ Scanning \\ Microscope \\ Article Info \\ Accepted: \\ 24 May 2019 \\ Available Online: \\ 10 June 2019}

\begin{abstract}
Metallo beta-lactamase (MBL) and biofilm production is the most worrisome resistant mechanisms observed in Pseudomonas aeruginosa. Increased resistance of Pseudomonas to antibiotic therapy is an emerging global health concern which can be overcomed by Silver nanoparticles (AgNPs). Therefore this study aims to evaluate the antibacterial and antibiofilm activity of Silver nanoparticles on MBL and biofilm producing $P$. aeruginosa isolates using Transmission Electron microscope (TEM) and Confocal laser scanning microscope (CLSM) respectively. A total 40 isolates of $p$. aeruginosa were screened for MBL production by combined disc test. Then the isolates were screened for biofilm forming ability by tissue culture plate assay. Commercially available Silver nanoparticles were obtained and tested against MBL and biofilm producing isolates. The antibacterial activity of AgNps was tested by MIC and MBC methods and by TEM. The CLSM results exhibited AgNPs concentration dependent inhibition of bacterial growth and EPS matrix of the biofilm. Therefore, AgNps serve as the next generation antimicrobials in protection against the biofilm mediated infections. It is suggested that coating of medical devices with silver nanoparticles is recommended for treatment of resistant bacterial infections.
\end{abstract}

\section{Introduction}

Pseudomonas aeruginosa is an important nosocomial pathogen which is a gramnegative motile bacillus, invasive and toxigenic. It causes serious infections, as bloodstream infection (BSI) that is considered as one of the most serious hospital-acquired infections (Chatzinikolaou et al., 2000). Also it has been implicated in urinary tract infections, burn infections, wounds infections, ventilator-associated pneumonia and multiorgan system failure (Rello et al., 2006). 
Pseudomonas aeruginosa shows a high level of intrinsic resistance to antimicrobial drugs and an ability to acquire other drug-resistant determinants by horizontal transfer of mobile genetic elements coding for class B carbapenemases also called metallo- $\beta$ lactamases (MBLs) which have become a serious concern in hospitals worldwide because they can be disseminated horizontally through transfer of resistance determinants (Cornaglia et al., 2011).

Pseudomonas aeruginosa may also acquire resistance to antibiotics due to permeability barrier of the cell surface in the form of biofilm production. The concentrations of antimicrobials required to achieve bactericidal activity against adherent organisms can be three to four fold higher than for those bacteria which do not produce biofilm (Gupta et al., 2016).

Although several new antibiotics were developed in the last few decades; none have improved the human fight against multidrugresistant bacteria. This makes major concern for the development of alternative and more effective therapeutic strategies to treat such resistant pathogens (Mohanty et al., 2012).

Nanoparticles are now considered a viable alternative to antibiotics and seem to have a high potential to solve the problem of the emergence of bacterial multidrug resistance (Rai et al., 2012).

Silver nanoparticles (AgNPs), have attracted much attention in the scientific field as they have antibacterial, anti-fungal, antiinflammatory, anti-viral, anti-angiogenic, and anti-cancer activities to overcome the drug resistance problem seen with Gram-negative and Gram-positive bacteria (Kora and Rastogi, 2013). Although the literature reports some studies related to the impact of AgNPs, there are very few studies concerning the efficacy of these particles against MBL and biofilm producing p. aeruginosa isolates. Therefore, this study aims to evaluate the antibacterial and anti biofilm activity of Silver nanoparticles (Ag-NP) on Metallo-betalactamase (MBL) and biofilm producing $P$. aeruginosa isolated from patients with nosocomial infections in both surgical ICU and pediatric ICU of Tanta University Hospital using Transmission Electron microscope (TEM) and Confocal laser scanning microscope (CLSM).

\section{Materials and Methods}

This study was carried out on100 patients showing criteria of nosocomial infections who were hospitalized in the surgical ICU(60 patients) and pediatric ICU (40 patients) of Tanta University Hospital, during the period of research from December 2016 to December 2017. The study included patients with invasive medical devices and risky patients with underlying chronic illness such as diabetes, hypertension and respiratory disease.

Patients who were colonized or immunosuppressed were excluded from the study. Written informed consent was obtained from all participants in the research.

The study was conducted at Medical Microbiology and Immunology department, Electron Microscopy Unit in Faculty of Medicine, Tanta University and in the Central Lab, Faculty of Veterinary Medicine, KafrELSheikh University.

Ethical approval for this study was provided by ethics and research committee, Faculty of Medicine, Tanta University.

\section{Collection of samples}

Clinical specimens of respiratory secretions, urine, wound swab and blood were received 
from surgical ICU patients and pediatric ICU patients who included in the study. The samples were transported to the laboratory of microbiology and processed within 30 minutes for isolation and identification of the causative pathogens. The isolates were identified as $P$. aeruginosa by conventional microbiological methods including microscopic examination, culture characteristics and biochemical reactions (Forbes et al., 2002).

The confirmed P.aeruginosa isolates were stored at $-20{ }^{\circ} \mathrm{C}$ in brain heart infusion broth containing $20 \%$ glycerol and subcultured for prior testing.

\section{Antimicrobial susceptibility testing}

Antimicrobial susceptibility of all the $P$. aeruginosa isolates was performed by KirbyBauer disc diffusion method using Clinical Laboratory Standards Institute guidelines CLSI (2017) criteria on Muller Hinton agar (Oxoid, UK). The following antibiotics were used Gentamycin $(10 \mu \mathrm{g})$, Imipenem( $(10 \mu \mathrm{g})$, Meropenem $(10 \mu \mathrm{g}), \quad$ Piperacillin $\quad(10 \mu \mathrm{g})$, Piperacillin Tazobactam $(10 \mu \mathrm{g})$, Ceftazidime $(30 \mu \mathrm{g})$, Cepfime $(30 \mu \mathrm{g})$, Ciprofloxacin $(5 \mu \mathrm{g})$, Aztreonam $(30 \mu \mathrm{g})$ and Colistin $(10 \mu \mathrm{g})$.

\section{Screening for MBL production}

\section{Imipenem (IMP)-EDTA combined disc test}

The IMP-EDTA combined disk test was performed as previously described by Yong et $a l ., 2002$. Test organisms were inoculated on to plates with Mueller Hinton agar as recommended by the CLSI, 2017. Two $10 \mu \mathrm{g}$ imipenem disks were placed on the plate, and appropriate amounts of $10 \mu \mathrm{L}$ of EDTA solution were added to one of them to obtain the desired concentration $(750 \mu \mathrm{g})$. The inhibition zones of the imipenem and imipenem- EDTA disks were compared after
16 to 18 hours of incubation in air at $35^{\circ} \mathrm{C}$. In the combined disc test, if the increase in inhibition zone with the Imipenem and EDTA disc was $\geq 7 \mathrm{~mm}$ than the Imipenem disc alone, it was considered as MBL positive.

\section{Detection of biofilm formation}

\section{Tissue culture plate method (TCP)}

The tissue culture plate (TCP) assay that described by Panda et al., 2016 is most widely used and was considered as standard test for detection of biofilm formation. $10 \mathrm{ml}$ of trypticase soy broth (TSB) with $1 \%$ glucose was inoculated with a loopful of test organism from overnight culture on nutrient agar and was incubated at $37^{\circ} \mathrm{C}$ for 24 hours. The culture was further diluted 1:100 with fresh medium and were incubated at $37^{\circ} \mathrm{C}$ for 24 hours. Only sterile broth was served as blank(negative control). After incubation gentle tapping of the plates was done. The wells were washed with $0.2 \mathrm{ml}$ of phosphate buffer saline $(\mathrm{pH}$ 7.2) four times to remove free floating bacteria. Biofilms which remained adherent to the walls and the bottoms of the wells, were fixed with $2 \%$ sodium acetate and stained with $0.1 \%$ crystal violet. Excess stain was washed with distilled water and plates were dried properly. Optical densities (OD) of stained adherent biofilm were obtained with a micro ELISA reader at wave length 570nm. Experiment was performed in triplicate. Intensity of biofilm was classified as described by Khanna et al., 2016. OD values greater than 0.240 were taken as Strong biofilm producer, OD values less than 0.120 as nonbiofilm producer and those between 0.120 and 0.240 were taken as moderate biofilm producers.

\section{Characterization of AgNPs}

A stock solution of commercially available water soluble spherical AgNPs $(19 \pm 5 \mathrm{~nm})$ with concentration $2200 \mathrm{ug} / \mathrm{ml}$ were purchased 
from Nano Tech, Egypt. Silver nanoparticles have been prepared by chemical reduction method as reported by manufacturer. A solution of AgNO 3 has been used as Ag 1+ ions precursor. The PVP has been used as stabilizing agent and borohydrate as mild reducing agent. The color of the solution slowly turned into grayish yellow, indicating the reduction of the $\mathrm{Ag} 1+$ ions to $\mathrm{Ag}$ nanoparticles

\section{High-resolution transmission electron microscopy}

\section{(HR-TEM) analysis of AgNPs}

The size and morphology of the NPs were analyzed by (HR-TEM). Samples were prepared by placing a drop of diluted suspension of NPs on carbon coated copper grid, and allowed to dry by evaporation at ambient temperature. The samples were kept in a desiccator until loaded on a specimen holder for analysis. TEM were performed on JEOL JEM-2100 high resolution transmission electron microscope at an accelerating voltage of $200 \mathrm{kV}$, respectively.

Evaluation of antibacterial activity of AgNPs by determination of MIC and MBC using broth microdilution method (Wiegand et al., 2008)

Different concentrations of AgNps were prepared using serial two fold dilutions starting from $400 \mathrm{ug} / \mathrm{ml}$ till $6.25 \mathrm{ug} / \mathrm{ml}$. Then preparation of bacterial suspension by colony suspension method. Bacterial inoculums of $2 \times 10^{8} \mathrm{CFU} / \mathrm{ml}$ were used in the experiments. The 96 well microdilution flat bottom plate was labelled with different concentrations of AgNps and 100 $\mu$ l of each concentrations were added to the wells. The treated and untreated samples were incubated at $37^{\circ} \mathrm{c}$ for $24 \mathrm{~h}$ after being covered with a lid then it was examined for MIC. The MIC was defined as the lowest concentration of antimicrobial agents that yielded no visible growth of the microorganisms. Subculture was performed from each MIC well on sterile nutrient agar plates and incubated aerobically at $37^{\circ} \mathrm{C}$ for 24h to record MBC. The MBC endpoint is defined as the lowest concentration of antimicrobial agent that kills $100 \%$ of the initial bacterial population.

Antibacterial activity of AgNPs by transmission electron microscopy (TEM)

The cells of $P$. aeruginosa isolates was prepared for TEM imaging as previously described by Schrand et al., 2010. Suspensions of these isolates were plated in 6well plates to prepare a $1 \mathrm{~mm}^{3}$ pellet. Dosing the cells with AgNPs at concentrations $3.125 \mathrm{ug} / \mathrm{ml}, 6.25,12,25,25 \mathrm{ug} / \mathrm{ml}$ for $24 \mathrm{~h}$ with a micropipetter and incubated. The treated and untreated control samples without AgNPs were fixed overnight with $2.5 \%$ glutaraldehyde. Samples were post fixed in $2 \%$ osmium tetraoxide, dehydrated in a series of graded ethanol, infiltrated and embedded in LR white resin. Then, ultra thin sections were cut, stained with uranyl acetate till imaging. The specimen was examined and photographed using JEOL, JEM-100SX electron microscope, Japan at The Electron Microscopic Unit, Faculty of Medicine, Tanta University.

\section{Antibiofilm activity of AgNPs by Confocal Laser Scanning Microscope (CLSM)}

Biofilm for confocal analysis were grown on glass coverslips in 6 well microtitre plate as previously described by Banas et al., 2001. Briefly, six well microtitre plate seeded with glass coverslips that were incubated for $24 \mathrm{~h}$ at $37{ }^{\circ} \mathrm{C}$ in $5 \mathrm{ml}$ of BHI broth with $5 \%$ sucrose. The wells were inoculated with 100 $\mu 1$ of overnight broth culture of the isolates for $24 \mathrm{~h}$ in the incubator. Silver nanoparticles 
were added to each well with concentration $25 \mathrm{ug} / \mathrm{ml}, 50 \mathrm{ug} / \mathrm{ml}$ and $100 \mathrm{ug} / \mathrm{ml}$. After $24 \mathrm{~h}$, the plate was gently washed with sterile PBS and then were stained with $15 \mu \mathrm{M}$ propidium iodide (Sigma) for $15 \mathrm{~min}$ at room temperature in order to detect red bacterial cells. After being washed in PBS, the cells were incubated with $50 \mu \mathrm{g} / \mathrm{ml}$ of concanavalin A-conjugated fluorescein isothiocyanate (Con-A FITC-Sigma) for $15 \mathrm{~min}$ at room temperature in the dark to stain the glycocalyx matrix green. All samples were examined immediately in the dark using CLSM imaging (Leica, Germany).The propidium iodide was excited at $520 \mathrm{~nm}$, the emission was monitored at $620 \mathrm{~nm}$, and Con A-FITC was excited and monitored at 495 and $525 \mathrm{~nm}$, respectively. The microscope was controlled by Leica Confocal software.

\section{Statistical analysis}

The collected data were organized, tabulated, and statistically analyzed using SPSS software (Statistical Package for the Social Sciences, version 23). Categorical data were summarized as numbers (percentages). Chisquare test or Fisher's exact test was used to test differences between the nominal data (frequencies). All $\mathrm{p}$ values less than 0.05 were considered significant.

\section{Results and Discussion}

\section{Prevalence and distribution of bacterial isolates}

A total of 40 p. aeruginosa isolates (33.3\%) were obtained from different clinical specimens in surgical ICU and pediatric ICU patients. Out of these, 12 isolates $(30 \%)$ were obtained from 11 pediatric ICU patients and 28 isolates $(70 \%)$ were obtained from 22 surgical ICU patients. The present study results showed that the highest percentage of isolates were from urine samples $(39.3 \%)$ in surgical ICU. While, samples from respiratory secretions $(50 \%)$ constitute the highest percentage in pediatric ICU (Table 1).

\section{Characteristics of study participants}

In surgical ICU patients, the age distribution among patients with $P$. aeruginosa isolates was as the following: 2 patients $(9.1 \%)$ below 40 years, 6 patients $(27.3 \%)$ between $40-60$ years and 14 patients $(63.6 \%)$ above 60 years with no significant difference ( $\mathrm{P}$ value $=0.477$ ). While the sex distribution was as the following: 16 patients $(72.7 \%)$ were male, and 6 patients $(27.3 \%)$ were females with no significant difference.

In pediatric ICU patients 3 patients $(27.3 \%)$ were below 2 months, $5(45.5 \%)$ were from 2 months to 5 years, 2 patients $(18.2 \%)$ were from 5 years to12 years and 1 patient $(9.1 \%)$ above 12 years with no significant difference between age and $P$. aeruginosa infections. Out of 11 patients, 8 patients $(72.7 \%)$ were males and 3 patients $(27.3 \%)$ were females with no significant difference between sex and $P$. aeruginosa infections (Table 2 and 3 ).

\section{Antimicrobial susceptibility testing}

The antibiogram pattern of $P$. aeruginosa isolates suggests that all isolates subjected to the study exhibited different resistant pattern against commonly used antibiotics. There was no resistance to colistin among all isolates with different degree of resistance to other antibiotics (Table 4).

The majority of isolates $(75 \%)$ were resistant to Ceftazidime followed by Cefipime (65\%), Piperacillin and Gentamycin (62.5\%), Imipenem (55\%), and Aztreonam (50\%). The most sensitive antimicrobials were Piperacillin tazobactam and Ciprofloxacin. 
Distribution of carbapenem resistant isolates

It was found that resistance to carbapenem was higher among isolates from pediatric ICU $(83.3 \%)$ than those from surgical ICU $(42.9 \%)$ with statistically significant difference between surgical ICU and pediatric ICU $(P$ value $=0.044 *)($ Table 5$)$.

Screening of metallo- $\beta$-lactamase producing $P$. aeruginosa (Imipenem-EDTA Disk Combined disc test)

In this study, $17 P$. aeruginosa isolates (77.3 $\%$ ) were found to be MBL producers. These results showed that $75 \%$ of surgical ICU patients were MBL positive. While, $80 \%$ of pediatric ICU patients were MBL positive with non significant difference $(P=0.781)$. These isolates exhibited $\mathrm{a} \geq 7 \mathrm{~mm}$ zone enhancement for Imipenem and EDTA combined than the Imipenem disks alone (Table 6).

\section{Detection of biofilm formation}

All of the 17 MBL positive $P$. aeruginosa isolates were subjected to Tissue Culture Plate Method. Out of which 6 isolates $(35.3 \%)$ were strong biofilm producer, 8 isolates $(47.1 \%)$ were moderate biofilm producer and 3 isolates(17.6\%) were non biofilm producer according to their optical density (Table 7).

\section{HR-TEM analysis of AgNPs}

HR-TEM analysis revealed that the AgNPs were predominantly spherical in shape. Significant variability in particle sizes was observed and the average size was estimated to be about $19 \pm 5 \mathrm{~nm}$ (Fig. 1). The HR-TEM images also revealed that AgNPs were not in aggregated state and appeared as mono dispersed.

\section{Antibacterial activity of AgNPs by MIC and $\mathrm{MBC}$ method}

The MIC and MBC values of AgNPs tested against biofilm producing MBL positive P.aeruginosa. About 10 isolates (71.5\%) exhibited the MIC of $6.25 \mathrm{ug} / \mathrm{ml}$ and MBC12.5 ug/ml. Whereas,4 isolates (28.5\%) shows the MIC of $12.5 \mathrm{ug} / \mathrm{ml}$ and $\mathrm{MBC}$ $25 \mathrm{ug} / \mathrm{ml}$. The isolates with higher MIC were isolated mainly from Surgical ICU (Table 8).

\section{Antibacterial activity of AgNPs by TEM}

The antibacterial effect of AgNps on biofilm producing MBL positive $P$. aeruginosa is also confirmed by TEM. Changes in the ultra structure of bacteria are photographed on exposure to different concentrations of $\mathrm{AgNps}$ $(3.125 \mathrm{ug} / \mathrm{ml}, \quad 6.25 \mathrm{ug} / \mathrm{ml}, 12.5 \mathrm{ug} / \mathrm{ml}$ and $25 \mathrm{ug} / \mathrm{ml}$ ). Figure 2a shows the untreated control cells of $P$. aeruginosa with intact smooth bacterial cell membrane without any indentations, leakage or damage in the membrane. The cells treated with increasing concentrations of AgNPs exhibited different morphological changes. These nanoparticles were attached to the surface of bacterial cell wall, permeated the cell membrane and entered into the cell interior with leakage of intracellular contents by cell disruption (Figure $2 \mathrm{~b}$-e).

\section{Antibiofilm activity of AgNPs by CLSM}

Confocal Laser Scanning Microscopic analysis of biofilms formation was studied in the MBL positive P.aeruginosa isolates. Bacterial cells stained red with Propidium Iodide (PI)were easily identified by their size and morphologic features. ConA-FITC binds to mannose residues resulting in green staining and indicating the presence of a bacterial glycocalyx. The presence of dark areas within the biofilm is attributed to the water channels, the heterogeneity of matrix and the types of EPSs within the biofilm. 
Table.1 Distribution of $P$. aeruginosa according to different types of samples

\begin{tabular}{|c|c|c|c|c|c|}
\hline \multicolumn{3}{|c|}{ Surgical ICU } & \multicolumn{3}{c|}{ Pediatric ICU } \\
\hline Type of sample & $\begin{array}{c}\text { Number of } \\
\text { samples }\end{array}$ & $\begin{array}{c}\text { Number of } \\
\text { isolated P.A } \\
(\%)\end{array}$ & Type of sample & $\begin{array}{c}\text { Number of } \\
\text { samples }\end{array}$ & $\begin{array}{c}\text { Number of } \\
\text { isolated P.A } \\
(\%)\end{array}$ \\
\hline $\begin{array}{c}\text { Respiratory } \\
\text { secretions }\end{array}$ & 14 & $8(28.6 \%)$ & $\begin{array}{c}\text { Respiratory } \\
\text { secretions }\end{array}$ & 14 & $6(50 \%)$ \\
\hline Wound swab & 9 & $4(14.3 \%)$ & Wound swab & 5 & $2(16.7 \%)$ \\
\hline Drain fluid & 4 & $2(7.1 \%)$ & Drain fluid & 2 & $0(0 \%)$ \\
\hline $\begin{array}{c}\text { Blood sample \& } \\
\text { catheter tip }\end{array}$ & 11 & $3(10.7 \%)$ & $\begin{array}{c}\text { Blood sample\& } \\
\text { catheter tip }\end{array}$ & 8 & $1(8.3 \%)$ \\
\hline Urine sample & 35 & $11(39.3 \%)$ & Urine sample & 18 & $3(25 \%)$ \\
\hline Total & 73 & $28(70 \%)$ & Total & 47 & $12(30 \%)$ \\
\hline
\end{tabular}

Table.2 Demographic data of Surgical ICU patients

\begin{tabular}{|c|c|c|c|c|}
\hline \multirow[b]{2}{*}{ Variables } & \multicolumn{2}{|c|}{ Surgical ICU patients $(\mathrm{N}=\mathbf{6 0})$} & \multirow[b]{2}{*}{$\chi^{2}$} & \multirow[b]{2}{*}{$\begin{array}{c}\text { p- } \\
\text { value }\end{array}$} \\
\hline & $\begin{array}{c}\text { Patients with } P \text {. aeruginosa } \\
\text { isolates }(\mathrm{N}=22)\end{array}$ & $\begin{array}{c}\text { Patients with non P. aeruginosa } \\
\text { isolates }(\mathrm{N}=38)\end{array}$ & & \\
\hline \multicolumn{5}{|l|}{ Age } \\
\hline $\begin{array}{c}\text { Below } 40 \\
\text { years }\end{array}$ & $2(9.1 \%)$ & $5(13.2 \%)$ & \multirow{3}{*}{1.482} & \multirow{3}{*}{0.477} \\
\hline $40-60$ years & $6(27.3 \%)$ & $15(39.5 \%)$ & & \\
\hline $\begin{array}{c}\text { Above } 60 \\
\text { years }\end{array}$ & $14(63.6 \%)$ & $18(47.4 \%)$ & & \\
\hline \multicolumn{5}{|l|}{ Sex } \\
\hline Male & $16(72.7 \%)$ & $23(60.5 \%)$ & \multirow{2}{*}{0.912} & \multirow{2}{*}{0.340} \\
\hline Female & $6(27.3 \%)$ & $15(39.5 \%)$ & & \\
\hline
\end{tabular}


Table.3 Demographic data of pediatric ICU patients

\begin{tabular}{|c|c|c|c|c|}
\hline \multirow[b]{2}{*}{ Variables } & \multicolumn{2}{|c|}{ Pediatric ICU patients $(\mathrm{N}=\mathbf{4 0})$} & \multirow[b]{2}{*}{$\chi^{2}$} & \multirow[b]{2}{*}{ p-value } \\
\hline & $\begin{array}{c}\text { Patients with } \\
\text { P. aeruginosa isolates } \\
(\mathrm{N}=11)\end{array}$ & $\begin{array}{c}\text { Patients with non } \\
\text { P. aeruginosa isolates } \\
(\mathrm{N}=29)\end{array}$ & & \\
\hline \multicolumn{5}{|l|}{ Age } \\
\hline Below 2 months & $3(27.3 \%)$ & $12(41.4 \%)$ & \multirow{4}{*}{1.244} & \multirow{4}{*}{0.742} \\
\hline 2-5 years & $5(45.5 \%)$ & $8(27.6 \%)$ & & \\
\hline 5-12 years & $2(18.2 \%)$ & $6(20.7 \%)$ & & \\
\hline Above 12 years & $1(9.1 \%)$ & $3(10.3 \%)$ & & \\
\hline \multicolumn{5}{|l|}{ Sex } \\
\hline Male & $8(72.7 \%)$ & $20(69 \%)$ & \multirow{2}{*}{0.054} & \multirow{2}{*}{0.817} \\
\hline Female & $3(27.3 \%)$ & $9(31 \%)$ & & \\
\hline
\end{tabular}

Table.4 Antimicrobial susceptibility pattern of $P$. aeruginosa isolates to different antimicrobial agent. $(\mathrm{N}=40)$

\begin{tabular}{|c|c|c|c|c|c|c|}
\hline \multirow{2}{*}{$\begin{array}{c}\text { Antimicrobial } \\
\text { Agent }\end{array}$} & \multicolumn{2}{|c|}{ Sensitive } & \multicolumn{2}{c|}{ Intermediate } & \multicolumn{2}{c|}{ Resistant } \\
\cline { 2 - 7 } & Number & $\%$ & Number & $\%$ & Number & $\%$ \\
\hline Piperacillin & 7 & $17.5 \%$ & 8 & $20 \%$ & 25 & $62.5 \%$ \\
\hline $\begin{array}{c}\text { Piperacillen } \\
\text { Tazobactam }\end{array}$ & 25 & $62.5 \%$ & 6 & $15 \%$ & 9 & $22.5 \%$ \\
\hline Ciprofloxacin & 22 & $55 \%$ & 6 & $15 \%$ & 12 & $30 \%$ \\
\hline Cefepime & 10 & $25 \%$ & 4 & $10 \%$ & 26 & $65 \%$ \\
\hline Ceftazidime & 8 & $20 \%$ & 2 & $5 \%$ & 30 & $75 \%$ \\
\hline Imipenem & 18 & $45 \%$ & 0 & $0 \%$ & 22 & $55 \%$ \\
\hline Meropenem & 18 & $45 \%$ & 0 & $0 \%$ & 22 & $55 \%$ \\
\hline Gentamicin & 8 & $20 \%$ & 7 & $17.5 \%$ & 25 & $62.5 \%$ \\
\hline Aztreonam & 17 & $42.5 \%$ & 3 & $7.5 \%$ & 20 & $50 \%$ \\
\hline Colistin & 40 & $100 \%$ & 0 & $0 \%$ & 0 & $0 \%$ \\
\hline
\end{tabular}


Table.5 Distribution of carbapenem resistant isolates among $P$. aeruginosa isolates $(\mathrm{N}=40)$

\begin{tabular}{|c|c|c|c|c|c|}
\hline & \multicolumn{3}{|c|}{ P. aeruginosa isolates } & \multirow{2}{*}{$\chi^{2}$} & \multirow{2}{*}{ P-value } \\
\hline & $\begin{array}{c}\text { Surgical ICU } \\
(\mathbf{n = 2 8})\end{array}$ & $\begin{array}{c}\text { Pediatric ICU } \\
(n=12)\end{array}$ & $\begin{array}{c}\text { Total } \\
(n=40)\end{array}$ & & \\
\hline $\begin{array}{l}\text { Carbapenem } \\
\text { resistant isolates }\end{array}$ & $12(42.9 \%)$ & $10(83.3 \%)$ & $22(55 \%)$ & \multirow{3}{*}{4.045} & \multirow{3}{*}{$0.044^{*}$} \\
\hline $\begin{array}{l}\text { Carbapenem } \\
\text { Sensitive isolates }\end{array}$ & $16(57.1 \%)$ & $2(16.7 \%)$ & $18(45 \%)$ & & \\
\hline Total & $28(70 \%)$ & $12(30 \%)$ & $40(100 \%)$ & & \\
\hline
\end{tabular}

Table.6 Results of Imipenem- EDTA test among carbapenem resistant isolates

\begin{tabular}{|c|c|c|c|c|c|}
\hline & \multicolumn{3}{|c|}{ Carbapenem resistant isolates } & \multirow[b]{2}{*}{$\chi^{2}$} & \multirow[b]{2}{*}{$\begin{array}{c}\mathrm{P}- \\
\text { value }\end{array}$} \\
\hline & $\begin{array}{c}\text { Surgical ICU } \\
(\mathbf{N}=12)\end{array}$ & $\begin{array}{c}\text { Pediatric } \\
\text { ICU }(\mathbf{N}=10)\end{array}$ & $\begin{array}{c}\text { Total } \\
(\mathrm{n}=22)\end{array}$ & & \\
\hline $\begin{array}{l}\text { MBL positive } \\
\text { isolates }\end{array}$ & $9(75 \%)$ & $8(80 \%)$ & $17(77.3 \%)$ & \multirow{3}{*}{0.078} & \multirow{3}{*}{0.781} \\
\hline $\begin{array}{l}\text { MBL negative } \\
\text { isolates }\end{array}$ & $3(25 \%)$ & $2(20 \%)$ & $5(22.7 \%)$ & & \\
\hline Total & $12(54.5 \%)$ & $10(45.5 \%)$ & $22(100 \%)$ & & \\
\hline
\end{tabular}

Table.7 Detection of biofilm formation by Tissue culture plate (TCP) method among MBL positive isolates $(\mathrm{N}=17)$

\begin{tabular}{|c|c|c|}
\hline \multirow{2}{*}{ Result of biofilm production } & \multicolumn{2}{|c|}{$\begin{array}{c}\text { MBL Positive p. aeruginosa isolates(N } \\
=17)\end{array}$} \\
\cline { 2 - 3 } & N & $\%$ \\
\hline - Negative $(\mathrm{OD}<0.12)$ & 3 & $17.6 \%$ \\
\hline Positive & 14 & $82.4 \%$ \\
$\checkmark$ Strong $(\mathrm{OD}>0.24)$ & 6 & $35.3 \%$ \\
$\checkmark$ Moderate $(0.12<\mathrm{OD}<0.24)$ & 8 & $47.1 \%$ \\
\hline
\end{tabular}


Table.8 Minimum inhibitory concentration (MIC) and Minimum bactericidal concentration (MBC) of Silver Nanoparticles (AgNps) against biofilm producing MBL positive $P$. aeruginosa isolates $(\mathrm{N}=14)$

\begin{tabular}{|c|c|c|c|c|}
\hline Isolate NO. & ICU & $\begin{array}{c}\text { Type of Biofilm } \\
\text { produced }\end{array}$ & $\begin{array}{c}\text { MIC } \\
(\mathbf{u g} / \mathrm{ml})\end{array}$ & MBC $(\mathbf{u g} / \mathrm{ml}$ \\
\hline 1 & Surgical ICU & Strong & $6.25 \mathrm{ug} / \mathrm{ml}$ & $12.5 \mathrm{ug} / \mathrm{ml}$ \\
\hline 2 & Surgical ICU & Strong & $6.25 \mathrm{ug} / \mathrm{ml}$ & $12.5 \mathrm{ug} / \mathrm{ml}$ \\
\hline 3 & Surgical ICU & Moderate & $6.25 \mathrm{ug} / \mathrm{ml}$ & $12.5 \mathrm{ug} / \mathrm{ml}$ \\
\hline 4 & Surgical ICU & Moderate & $6.25 \mathrm{ug} / \mathrm{ml}$ & $12.5 \mathrm{ug} / \mathrm{ml}$ \\
\hline 5 & Surgical ICU & Moderate & $6.25 \mathrm{ug} / \mathrm{ml}$ & $12.5 \mathrm{ug} / \mathrm{ml}$ \\
\hline 6 & Surgical ICU & Moderate & $6.25 \mathrm{ug} / \mathrm{ml}$ & $12.5 \mathrm{ug} / \mathrm{ml}$ \\
\hline 7 & Pediatric ICU & Moderate & $6.25 \mathrm{ug} / \mathrm{ml}$ & $12.5 \mathrm{ug} / \mathrm{ml}$ \\
\hline 8 & Surgical ICU & strong & $12.5 \mathrm{ug} / \mathrm{ml}$ & $25 \mathrm{ug} / \mathrm{ml}$ \\
\hline 9 & Surgical ICU & strong & $12.5 \mathrm{ug} / \mathrm{ml}$ & $25 \mathrm{ug} / \mathrm{ml}$ \\
\hline 10 & Surgical ICU & Strong & $12.5 \mathrm{ug} / \mathrm{ml}$ & $25 \mathrm{ug} / \mathrm{ml}$ \\
\hline 11 & Pediatric ICU & Strong & $12.5 \mathrm{ug} / \mathrm{ml}$ & $25 \mathrm{ug} / \mathrm{ml}$ \\
\hline 12 & Pediatric ICU & Moderate & $6.25 \mathrm{ug} / \mathrm{ml}$ & $12.5 \mathrm{ug} / \mathrm{ml}$ \\
\hline 13 & Pediatric ICU & Moderate & $6.25 \mathrm{ug} / \mathrm{ml}$ & $12.5 \mathrm{ug} / \mathrm{ml}$ \\
\hline 14 & Pediatric ICU & Moderate & $6.25 \mathrm{ug} / \mathrm{ml}$ & $12.5 \mathrm{ug} / \mathrm{ml}$ \\
\hline
\end{tabular}




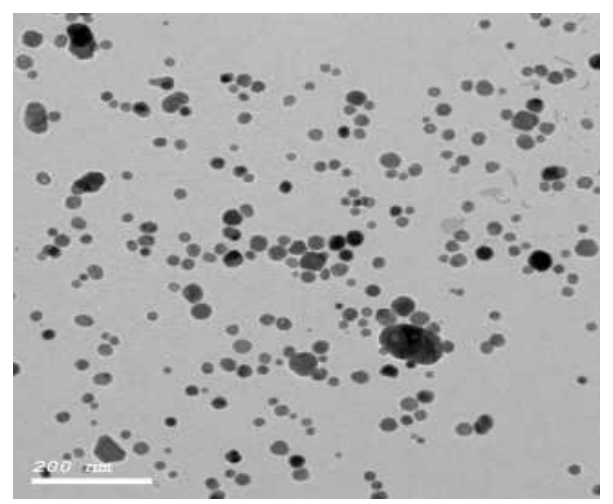

Fig.1: Transmission electron microscope (TEM) image of silver nanoparticles shows spherical shaped particles with average diameter of about $19 \pm 5 \mathrm{~nm}$.
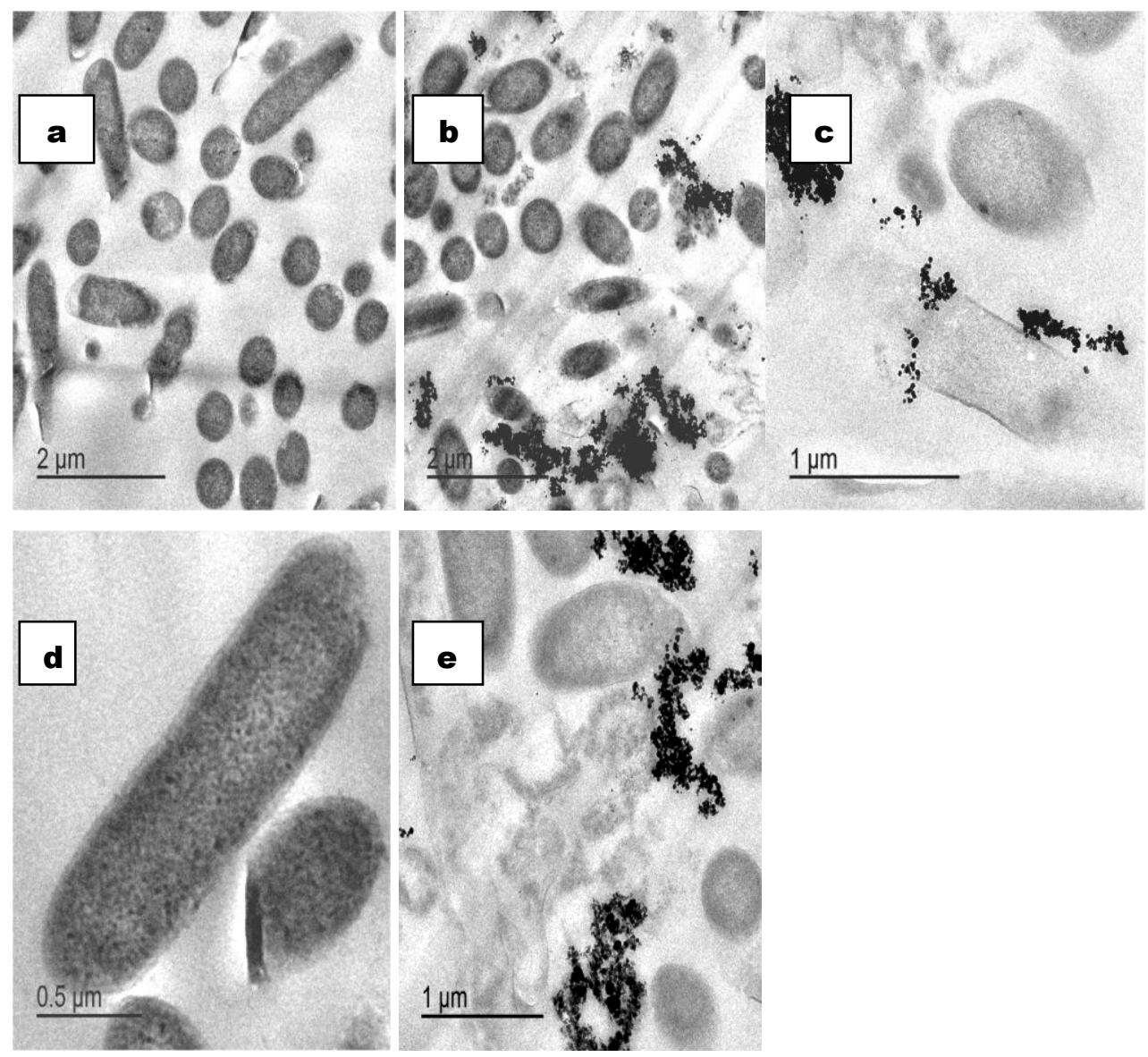

Fig2 : Transmission electron microscope (TEM) image of $P$. aeruginosa (MBL and biofilm producing isolates). The images are represented as (a) untreated (control sample), (b) treated with $3.125 \mathrm{ug} / \mathrm{ml},(\mathbf{c})$ treated with6. $25 \mathrm{ug} / \mathrm{ml},(\mathbf{d})$ treated with $12.5 \mathrm{ug} / \mathrm{ml},(\mathbf{e})$ treated with $25 \mathrm{ug} / \mathrm{ml}$. 


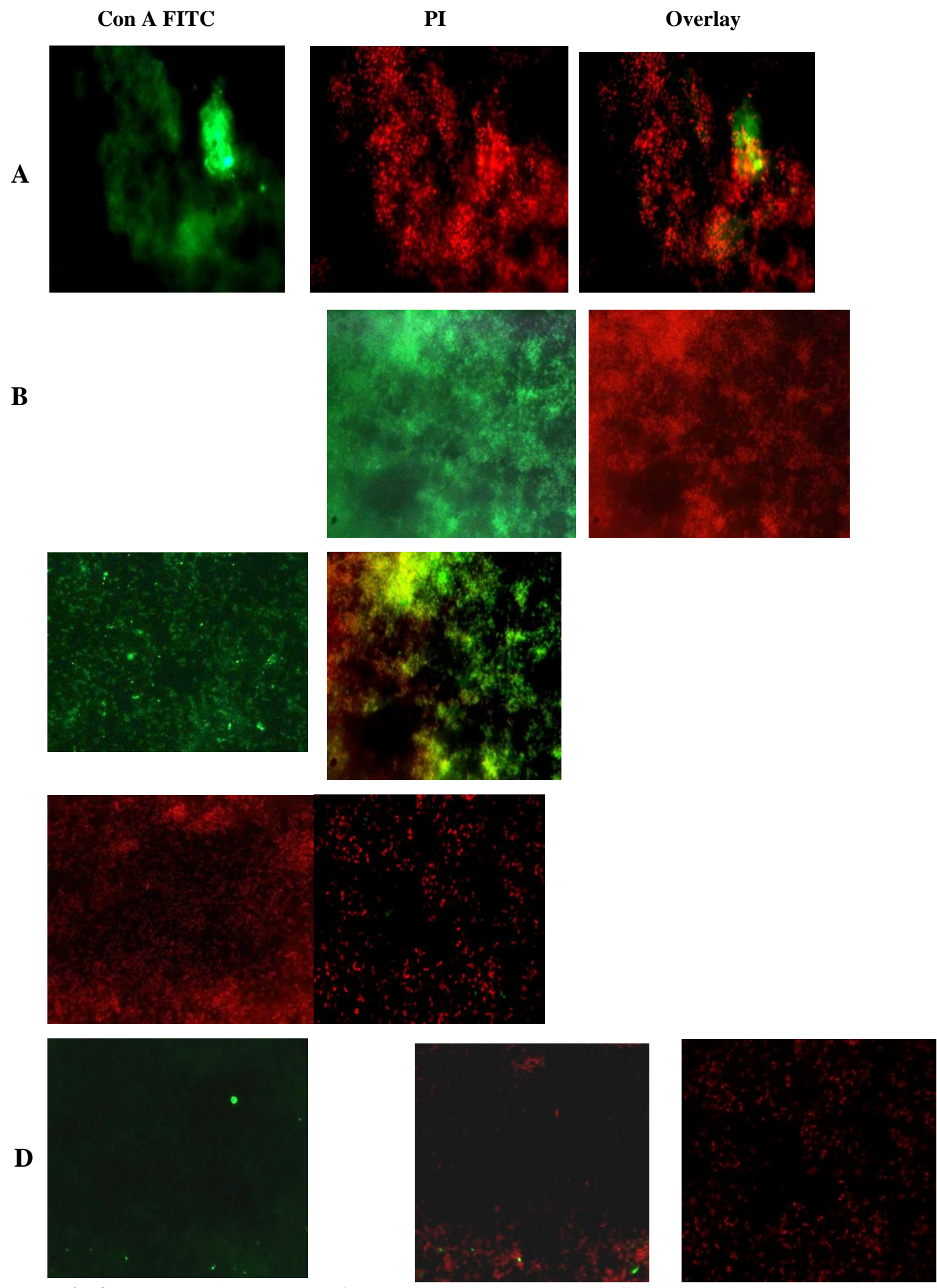

Fig.3: C LSM micrographs of $P$. aeruginosa isolates ( biofilm producing and positive MBL) . The panel (a) represents images of untreated control $P$. aeruginosa isolate. Red color depicts the PI staining of bacterial nucleic acids and green fluorescent staining with ConA-FITC indicates the presence of EPSs. The panels( b-d ) represent images of $P$. aeruginosa isolate treated with $25 \mathrm{ug} / \mathrm{ml}(\mathbf{b}), 50 \mathrm{ug} / \mathrm{ml}(\mathbf{c})$, and $100 \mathrm{ug} / \mathrm{ml}(\mathbf{d}) \mathrm{ug} / \mathrm{ml}$ of AgNPs. (Magnification at $\times$ 400) 
Also, the interconnected bacteria were found encased in a scaffolding network composed of extracellular matrix, suggesting a 3dimensional architecture of biofilm formations. Figure $3 \mathrm{a}$ exhibit the biofilm formation in absence of AgNPs (Control sample) with a definite architecture. However, in the presence of AgNPs (Figure 3b-d) a scanty growth with few cells was observed with no distinct pattern of arrangement. The maximal biofilm inhibition was noticed at $100 \mathrm{ug} / \mathrm{ml}$ of AgNPs.

Pseudomonas aeruginosa emerged as an important pathogen responsible for the nosocomial infections that is one of the important causes of morbidity and mortality among hospitalized patients (Khan et al., 2008). In the present study, the percentages of P.aeruginosa isolates were $33.3 \%$ from both surgical ICU and pediatric ICU and most frequently samples in Pediatric ICU were from respiratory secretions $(50 \%)$ while urine samples represents the commonest in surgical ICU. which were in agreement with Gupta et al., (2016) who found that p.aeruginosa represented $28 \%$ of the total isolates in ICU frequently isolated from LRTI $(40 \%)$. On the other hand, this result was not comparable with that of Al-Ghamdi et al., (2002) who reported that LRTIs represented $8.9 \%$ of cases. Higher percentages of P.aeruginosa isolated from urinary tract infections as reported by Taj et al., (2018).

Regarding the sex distribution of P.aeruginosa patients in surgical ICU, 16 cases $(72.7 \%)$ were males and 6 cases (27.3). These results were matched with the studies carried out by Mahmoud et al., (2013) and Mohamed (2016). According to Humphreys et al., (2015) males are more prone to infection due to behavioral and immunological factors. As they are less compliant to hand hygiene practice.
The present study reported that $63.6 \%$ of P.aeruginosa patients in Surgical ICU were above 60 years as confirmed by earlier studies by Hefni et al., (2013) and Tsao et al., (2018).

Pseudomonas aeruginosa is highly resistant pathogen because of intrinsic resistance and rapid acquisition of additional resistance, which often makes these infections difficult to treat (Alikhani et al., 2014).

According to the antibiogram of isolated $P$. aeruginosa, the highest rate of sensitivity were towards colistin (100\%) followed by piperacillin tazobactam (62.5\%), ciprofloxacin (55\%), imipenem and meropenem (45\%), aztreonam (42.5\%), cefipime $(25 \%)$, ceftazidime and gentamycin $(20 \%)$, aztreonam (15\%).

This finding is in agreement with the study of Singh and Tolpadi, (2018)who reported higher rate of sensitivity of $P$. aeruginosa were towards Piperacillin- tazobactam (77\%) and Ciprofloxacin(73\%).

In comparison to our result, an Egyptian study by Hefni, et al.,(2013) reported that $P$. aeruginosa isolates were most sensitive to Imipenem (100\%), Meropenem (100\%),Gentamicin (100\%) and Amikacin $(100 \%)$ followed by Ceftazidime (95\%), Levofloxacin (90\%).

Regional variation in antibiotic sensitivity pattern for $P$. aeruginosa in different studies may be attributed to different antibiotic prescribing habits (Singh and Tolpadi, 2018).

In the present study carbapenem resistance was55\% with statistically significant difference between surgical ICU and pediatric ICU. Our result also more or less correlates with the study of Devi et al., (2017) who found that $42 \%$ of $P$. aeruginosa isolates were imipenem resistant in surgical ICU and 
pediatric ICU. On the other hand, lower incidence of carbapenem resistant $P$. aeruginosa $(10.2 \%)$ was observed by Lin et al.,(2016).

These varied prevalence rate of carbapenem resistant $P$. aeruginosa was explained by Chen et al., (2013) who stated that different geographic areas, patient population, and clinical setting were the main reasons for these different results.

Metallo Beta Lactamase has been identified from clinical isolates worldwide with increasing frequency over the past several years. They are associated with prolonged nosocomial infections with a higher morbidity and mortality among the patients (Nag Kumar et al., 2015). In this study, $75 \%$ of $p$. aeruginosa isolates in surgical ICU were MBL positive and $80 \%$ of isolates in pediatric ICU were MBL positive with no significant difference.

This result was in agreement with Kali et al.,(2013) who reported $72.70 \%$ of $P$. aeruginosa isolates were MBL producers. However, Nisha et al., (2016) reported 23\% MBL producers.

Biofilms have an enormous impact on healthcare and are estimated to be associated with $65 \%$ of infections in ICU patients (Høiby et al., 2010). In this study, $82.4 \%$ of MBL positive P.aeruginosa were biofilm producers. Out of this biofilm producer isolates $35.3 \%$ were strong biofilm producer and $47.1 \%$ were moderate biofilm producer. These results were more or less similar to Gonçalves et al., (2017) who reported 100\% of MBL positive strains were strong biofilm producers. Furthermore, Sanchez et al., (2013) reported that $83 \%$ of P.aeruginosa isolates were biofilm producer. Nevertheless, a Brazilian study by Perez et al., (2012) found that $40 \%$ of MBL positive $P$. aeruginosa were strong biofilm producer.
On evaluation the antibacterial activity of AgNps in this study, the MIC was $6.25 \mathrm{ug} / \mathrm{ml}$ for $71.5 \%$ of biofilm and MBL positive $p$. aeruginosa isolates. While, the MIC was 12.5 $\mathrm{ug} / \mathrm{ml}$ in $28.5 \%$ of isolates. These results were in line with Singh et al., (2014) who noted that the MIC of AgNPs was found to be in a range from $6.25-12.5 \mu \mathrm{g} / \mathrm{ml}$, against MDR strains of P.aeruginosa. Whereas, Yang et al., (2009) reported lower MIC of AgNPs at 0.3$3 \mathrm{ug} / \mathrm{ml}$ for $P$. aeruginosa.

Contrarily, Panáček et al., (2006) reported higher inhibitory concentration of $\mathrm{AgNps}$ at $27 \mathrm{ug} / \mathrm{ml}$ for a standard reference strain of $P$. aeruginosa.

The antibacterial activity of AgNPs was different as it depends on morphology of AgNPs, type of strain (resistant or sensitive), microbial inherent sensitivity and cell wall composition (Abdeen et al., 2014).

Out TEM results also revealed different morphological changes in $p$. aeruginosa at different concentrations of AgNPs which support the observations of earlier studies (Sondi and Salopek-Sondi 2004; Morones et al., 2005; Raffi et al., 2008).

Morones et al., (2005) explained the antibacterial mechanism of $\mathrm{AgNps}$ as it attached to the cell membrane and had a higher affinity to react with phosphorus and sulfur compounds. On the other hand, Fenget al.,(2000) found that nanoparticles react with DNA causing damage in processes as respiratory chain, and cell division, finally causing the death of the cell. However, the exact mechanism of action of AgNps is not very clear. Different authors have described mode of action in different ways.

The demonstration of bacterial biofilms is often challenging because of the problem in concurrent staining of both the bacterial cells and EPS. Our results obtained with the 
double-staining technique using CLSM revealed maximal inhibition of biofilm formation at concentrations $100 \mathrm{ug} / \mathrm{ml}$ of AgNps. These results were similar to previous studies by Kalishwaralal et al., (2010) against P.aeruginosa and S.epidermidis biofilms.

Moreover, Ansari et al., (2014) concluded that $95 \%$ reduction in biofilm in isolates of E.coli and Klebsiella spp was at $50 \mu \mathrm{g} / \mathrm{ml}$ of AgNPs.

In conclusion, carbapenem resistant $p$. aeruginosa is widely distributed in ICUs with MBLs production which is the most prevalent mechanism of resistance. Therefore, screening of all carbapenem resistant isolates for MBL production is necessary for notification to infection control teams to limit their spread and decrease its incidence by infection control measures. The AgNPs are suggested as effective antimicrobial and antibiofilm activity against $P$. aeruginosa.

\section{Acknowledgments}

I would like to profusely thank the staff of Microbiology laboratory of Infection Control Unit, Faculty of Medicine, Tanta University for their cooperation in the collection of isolates used in this study.

\section{Conflict of interest}

There is no conflict of interest between the authors.

\section{Abbreviations}

MBL: Metallo beta lactamase; AgNps: Silver nanoparticles; TEM: Transmission Electron Microscope; CLSM: Confocal Laser Scanning Microscope; MIC: Minimum inhibitory concentration; MBC: Minimum bactericidal concentration

\section{References}

Al-Ghamdi S, Gedebou M, Bilal NE, 2002. Nosocomial infections and misuse of antibiotics in a provincial community hospital, Saudi Arabia. J Hosp Infec. 50:115-21.

Alikhani MY, Karimi Tabar Z, Mihani F, Kalantar E, Karami P, Sadeghi M, Ahdi Khosroshahi S, Farajnia S., 2014. Antimicrobial resistance patterns and prevalence of blaPER-1 and blaVEB-1 genes among ESBLproducing Pseudomonas aeruginosa isolates in west of Iran. Jundishapur J Microbiol. 7: 1-5.

Ansari MA, Khan HM, Khan AA, Cameotra SS, Pal R., 2014. Antibiofilm efficacy of silver nanoparticles against biofilm of extended spectrum $\beta$-lactamase isolates of Escherichia coli and Klebsiella pneumoniae. Applied Nanoscience. 4(7):859-68.

Banas JA, Hazlett KRO, Mazurkiewicz JE., 2001. An in vitro model for studying the contributions of the Streptococcus mutans glucan-binding protein-A to biofilm structure. Meth Enzymol. 337:425-433.

Chatzinikolaou I, Abi-Said D, Bodey GP, Rolston KV, Tarrand JJ, Samonis G., 2000. Recent experience with Pseudomonas aeruginosa bacteremia in patients with cancer: retrospective analysis of 245 episodes. Archives of Internal Medicine. 28; 160(4): 501-9.

Chen IL, Lee CH, Su LH, Tang YF, Chang SJ, Liu JW., 2013. Antibiotic consumption and healthcareassociated infections caused by multidrug-resistant gram-negative bacilli at a large medical center in Taiwan from 2002 to 2009: implicating the importance of antibiotic stewardship. PloS One. $8(5): 1-6$. 
Cornaglia G, Giamarellou H and Rossolini GM., 2011. Metallo- $\beta$-lactamases: a last frontier for $\beta$-lactams? The Lancet Infectious Diseases. 11(5):381-93.

Devi PV, Reddy PS, John MS., 2017. Incidence of carbapenem resistant nonfermenting gram negative bacilli from patients with respiratory tract infections among intensive care units. International Journal of Research in Medical Sciences. 3(6):1368-1371.

Forbes BA, Sahm DF, Weissfeld AS., 2002. Diagnostic microbiology. Bailey \& Scott1s Diagnostic Microbiology. 11(1):11-14.

Gonçalves IR, Dantas RC, Ferreira ML, Batistão DW, Gontijo-Filho PP, Ribas RM., 2017. Carbapenem-resistant Pseudomonas aeruginosa: association with virulence genes and biofilm formation. Brazilian Journal of Microbiology. 48(2):211-217.

Gupta R, Malik A, Rizvi M, Ahmed SM., 2016. Incidence of multidrug-resistant pseudomonas spp. in ICU patients with special reference to ESBL, AMPC, MBL and biofilm production. Journal of Global Infectious Diseases. 8(1):25-31.

Hefni AAH, Ibrahim AMR, Attia KM, Moawad MM, El ramah AF, Shahin MM, Al-Satar LA., 2013. Bacteriological study of diabetic foot infection in Egypt. Journal of the Arab Society for Medical Research. 8(1):26-32.

Høiby N, Bjarnsholt T, Givskov M, Molin S, Ciofu O., 2010 Antibiotic resistance of bacterial biofilms. International journal of antimicrobial agents. 35(4):322-32.

Humphreys H, Fitzpatick F, Harvey BJ., 2015. Gender differences in rates of carriage and bloodstream infection caused by methicillin-resistant Staphylococcus aureus: are they real, do they matter and why? Clinical Infectious Diseases. 61(11):17081714.

Kali A, Srirangaraj S, Kumar S, Divya HA, Kalyani A, Umadevi S., 2013. Detection of metallo-beta- lactamase producing Pseudomonas aeruginosain intensive care units. AMJ. 12:686-693.

Kalishwaralal K, BarathManiKanth S, Pandian SR, Deepak V, Gurunathan S., 2010. Silver nanoparticles impede the biofilm formation by Pseudomonas aeruginosa and Staphylococcus epidermidis. Colloids and Surfaces B: Biointerfaces. 79(2):340-344.

Khan JA, Iqbal Z, Rahman SU, Farzana K, Khan A., 2008. Prevalence and Resistance Pattern of Pseudomonas aeruginosa against Various Antibiotics. Pak J Pharm Sci. 21(3):311-315.

Khanna P, Devi P, Devi B., 2016. Prevalence of biofilm production by Staphylococcus species isolated from References - 145 - patients on indwelling medical devices/implants. International Journal of Current Microbiology and Applied Sciences. 3: 667-675.

Kora AJ, Rastogi L., 2013. Enhancement of antibacterial activity of capped silver nanoparticles in combination with antibiotics, on model gram-negative and gram-positive bacteria. Bioinorg Chem Appl. 1-7.

Lin KY, Lauderdale TL, Wang JT, Chang SC., 2016. Carbapenem-resistant Pseudomonas aeruginosa in Taiwan: Prevalence, risk factors, and impact on outcome of infections. Journal of Microbiology, Immunology and Infection. 49(1):52-59.

Mahmoud AB, Zahran WA, Hindawi GR, Labib AZ, Galal R., 2013. Prevalence of multidrug-resistant Pseudomonas 
aeruginosa in patients with nosocomial infections at a University Hospital in Egypt, with special reference to typing methods. J Virol Microbiol. 10-13.

Mohamed H., 2016. One year prevalence of critically ill burnwound bacterial infections in surgical ICU in Egypt: Retrospective study.Egyptian Journal of Anaesthesia. 32(3):431-434.

Mohanty S, Mishra S, Jena P, Jacob B, Sarkar B, Sonawane A., 2012. An investigation on the antibacterial, cytotoxic, and antibiofilm efficacy of starch-stabilized silver nanoparticles. Nanomed: Nanotechnology Biology Medicine. 8: 916-924.

Morones JR, Elechiguerra JL, Camacho A, Holt K, Kouri JB, Ramirez JT, Yacaman MJ., 2005. The bactericidal effect of silver nanoparticles. Nanotechnology. 16:2346-2353.

NagKumar KP, Rahman SS, Bindu Hima M, Vadla S, Reddy M, Indu K., 2015. Antibiotic sensitivity pattern and imipenem-EDTA double disk synergy test for the detection of Metallo-betalactamase producing Pseudomonas aeruginosa from clinical samples in a teaching hospital. Int J Curr Microbiol App Sci. 4(5):866-71.

Nisha. C. Karanje, Saumya Singh, SaralGhosh. Karanje NC, Singh S, Ghosh S., 2016. A Study of Metallo beta lactamase Producing Pseudomonas aeruginosa in Patients attending D.Y. Patil Hospital and Research Centre, Kolhapur. IOSR Journal of Dental and Medical Sciences (IOSR- JDMS). 15(1):51-55. N, Sharma VK, Nevěčná TJ, Zbořil R., 2006. Silver colloid nanoparticles: synthesis, characterization, and their antibacterial activity. The Journal of Physical Chemistry. 110(33):162481653.
Panda PS, Chaudhary U, Dube SK., 2016. Comparison of four different methods for detection of biofilm formation by uropathogens. Indian Journal of Pathology and Microbiology. 59: 177179.

Perez LR, Antunes AL, Freitas AL, Barth AL., 2012. When the resistance gets clingy: Pseudomonas aeruginosa harboring metallo- $\beta$-lactamase gene shows high ability to produce biofilm. European Journal of Clinical Microbiology \&Infectious Diseases. 31(5):711-714.

Raffi M, Hussain F, Bhatti TM, Akhter JI, Hameed A, Hasan MM., 2008. Antibacterial characterization of silver nanoparticles against E: coli ATCC15224. J Mater Sci Technol. 24:192196.

Rai MK, Deshmukh SD, Ingle AP, Gade AK., 2012. Silver nanoparticles: The powerful nanoweapon against multidrug-resistant bacteria. J Appl Microbiol. 112:841-852.

Rello J, Allegri C, Rodriguez A, Vidaur L, Sirgo G, Gomez F, Agbaht K, Pobo A, Diaz E., 2006. Risk factors for ventilator-associated pneumonia by Pseudomonas aeruginosa in presence of recent antibiotic exposure. Anesthesiology: The Journal of the American Society of Anesthesiologists. 105(4):709-14.

Sanchez CJ, Mende K, Beckius ML, Akers KS, Romano DR, Wenke JC, Wenke JC, Murray CK., 2013. Biofilm formation by clinical isolates and the implications in chronic infections. BMC Infect Dis. 13:1-12.

Schrand AM, Schlager JJ, Dai L, Hussain SM., 2010. Preparation of cells for assessing ultrastructural localization of nanoparticles with transmission electron microscopy. Nature Protocols. 5(4):744-757. 
Singh, K., Panghal M, Kadyan S, Chaudhary U, Yadav JP., 2014. Green silver nanoparticles of Phyllanthus amarus: as an antibacterial agent against multi drug resistant clinical isolates of Pseudomonas aeruginosa. Journal of Nanobiotechnology. 12(1):1-9.

Singh, P., Tolpadi A., 2018. Antibiotic susceptibility profile and detection of metallo-beta lactamase in Pseudomonas aeruginosa isolates from clinical specimens in a tertiary care hospital. Indian Journal of Applied Research. 8(2):1-3.

Taj, A., Shamim A, Khanday SB, Ommid M., 2018. Prevalence of common nosocomial organisms in surgical intensive care unit in North India: A hospital-based study. International Journal of Critical Illness and Injury Science. 8(2): 78-82.

Tsao LH, Hsin CY, Liu HY, Chuang HC, Chen LY, Lee YJ., 2018. Risk factors for healthcare-associated infection caused by carbapenem-resistant Pseudomonas aeruginosa. Journal of Microbiology, Immunology and Infection. 51(3):359-66.

Wiegand I, Hilpert K, Hancock RE., 2008. Agar and broth dilution methods to determine the minimal inhibitory concentration (MIC) of antimicrobial substances. Nature protocols. $\mathrm{Feb} ; 3(2): 163$.

Yang FC, Wu KH, Liu MJ, Lin WP, Hu MK., 2009. Evaluation of the antibacterial efficacy of bamboo charcoal/silver biological protective material. Materials Chemistry and Physics. 113(1): 474-479.

Yong D, Lee K, Yum JH, Shin HB, Rossolini GM, Chong Y., 2002. ImipenemEDTA disk method for differentiation of metallo- $\beta$-lactamase-producing clinical isolates of Pseudomonas spp. and Acinetobacter spp. Journal of clinical microbiology. Oct 1. 40(10): 3798-801.

\section{How to cite this article:}

Marwa Gamal Bahey, Abou El Fetouh Eid El Enany, Mohamed Ismaeil Abd El Hamid, Aziza Mahmoud Hassan and Lobna Mohamed Abo Elnasr. 2019. In vitro Study on the Efficacy of Silver Nanoparticles against Metallo-Beta-Lactamase and Biofilm Producing Pseudomonas aeruginosa Isolates. Int.J.Curr.Microbiol.App.Sci. 8(06): 2931-2948.

doi: https://doi.org/10.20546/ijcmas.2019.806.352 